\title{
Determination of chemical parameters and storage stability of extra virgin olive oil extracted by Mobile Olive Oil Processing Unit
}

\author{
Esmaeil Ghanbari Shendi ${ }^{1, *}$, Dilek Sivri Ozay ${ }^{1}$, Mucahit Taha Ozkaya ${ }^{2}$ and Nimeti Feyza Ustunel ${ }^{3}$ \\ ${ }^{1}$ Hacettepe University, Department of Food Engineering, Ankara 06800, Turkey \\ 2 Ankara University, Department of Horticulture, Ankara 06110, Turkey \\ ${ }^{3}$ Nar Doğal Ürünler Tur. Tic. San. A.S., Ümraniye-İstanbul, Turkey
}

Received 31 May 2019 - Accepted 10 January 2020

\begin{abstract}
The effects of storage time on the stability and quality of cold press extra virgin olive oils (EVOO) extracted from cv. Tavşan Yüreği locally grown in Antalya Region of Anatolia was investigated. The Mobile Olive Oil Processing Unit (TEM Oliomio 500-2GV, Italy) was designed and used for the monocultivar olive oil production. Changes on the free fatty acid, peroxide value, UV absorption values, total phenol content, phenolic and tocopherol profiles, and sensory properties of EVOO samples were determined for 12 months. Results showed that fresh "Tavşan Yüreği" EVOO was classified as EVOO declared by the International Olive Council (IOC) standards-based in terms of chemical and sensory properties. It had a sensory profile with an equilibrated taste of intense fruitiness and medium bitterness and pungency at the end of one year. Although positive attributes (fruitiness, bitterness, and pungency) slightly decreased, color values of EVOO changed from green to yellow. Although total phenols content of EVOO samples were $385.27 \pm 0.908 \mathrm{ppm}$ at the beginning of storage, it decreased to $327.58 \pm 0.212 \mathrm{ppm}$ after a year storing. Luteolin was the most abundant phenolic compound and its content decreased by $14 \%$ at the end of storage, while tyrosol content of EVOO increased from 12 to $36.17 \mathrm{ppm}$. After twelve months, $\alpha$-tocopherol contents decreased 22.38\%. Using Mobile Olive Oil Processing Unit increased oxidative stability and quality of extracted EVOO.
\end{abstract}

Keywords: olive oil / Tavşan Yüreği / quality / phenolic compounds / storage

Résumé - Détermination des paramètres chimiques et stabilité durant le stockage de l'huile d'olive extra vierge extraite par une unité mobile de traitement. Les effets du temps de stockage sur la stabilité et la qualité des huiles d'olive extra vierges pressées à froid extraites du cultivar Tavşan Tavşan cultivé localement dans la région d'Antalya en Anatolie ont été étudiés. L'unité mobile de traitement de l'huile d'olive (TEM Oliomio 500-2GV, Italie) a été conçue et utilisée pour la production d'huile d'olive monocultivar. Les évolutions des acides gras libres, de l'indice de peroxyde, des valeurs d'absorption UV, de la teneur totale en phénol, des profils phénoliques et tocophériques, et des propriétés sensorielles des échantillons d'huiles ont été déterminées pendant 12 mois. Les résultats ont montré que l'huile d'olive fraîche «Tavşan Tavşan » était classée comme extra vierge par le Conseil oléicole international (COI) selon les normes reposant sur les propriétés chimiques et sensorielles. Elle présentait un profil sensoriel avec un goût équilibré de fruité intense et une amertume et un piquant moyens au bout d'un an. Bien que les attributs positifs (fruité, amertume et piquant) aient légèrement diminué, les valeurs de couleur de l'huile d'olive extra vierge sont passées du vert au jaune. Bien que la teneur totale en phénols des échantillons ait été de $385,27 \pm 0,908 \mathrm{ppm}$ au début de l'entreposage, elle a diminué à $327,58 \pm 0,212 \mathrm{ppm}$ après un an d'entreposage. La lutéoline était le composé phénolique le plus abondant et sa teneur a diminué de $14 \%$ à la fin de l'entreposage, tandis que la teneur en tyrosol a augmenté de 12 à $36,17 \mathrm{ppm}$. Après douze mois, la teneur en $\alpha$-tocophérol a diminué de $22,38 \%$. L'utilisation de l'unité mobile de traitement de l'huile d'olive a augmenté la stabilité oxydative et la qualité de l'huile extraite.

Mots clés : huile d'olive / Tavşan Tavşan / qualité / composés phénoliques / stockage

*Correspondence: esi.1361@gmail.com 


\section{Introduction}

Extra virgin olive oil (EVOO) is virgin olive oil which has a free acidity, expressed as oleic acid, of not more than $0.8 \mathrm{~g}$ per $100 \mathrm{~g}$, and the other characteristics of which correspond to those fixed for this category in this standard (IOC Regulation, 2013). Extra virgin olive oil (EVOO) is extracted from the olive fruit by using physical methods and it is ready to consume after extraction without refining. So, it conserves many natural bioactive compounds such as vitamins, phenolics, and sterols as well as a good balance of fatty acids. EVOO has a unique aroma, taste, color and nutritive features which identify it from other edible vegetable oils. The chemical composition of olive oil varies depending on the genetic, geographic, agronomic and process and storage (Boskou, 2006). Shelf life of virgin olive oil is longer than other edible oils, because of the presence of antioxidants such as biophenols and $\alpha$-tocopherol. Major and minor compounds such as free fatty acids, unsaturated hydrocarbons, enzymes, pigments and trace of metals were affected negatively due to storage time and storage conditions. Storage of olive oil under nitrogen pressure in a dark place at room temperature (25$30{ }^{\circ} \mathrm{C}$ or lower) increases shelf life (Boskou, 2006). Conflicting results were reported on the effect of storage on the unsaturated fatty acid composition in the literature. A decrease in chlorophyll and carotenoid contents and an increase of oleic acid percentage were also reported ( Morelló et al., 2004). This increase of oleic acid percentage has been found in the fatty acid composition as a result of the degradation of polyunsaturated acids (linoleic acid and linolenic acid). Vitamin E ( $\alpha$-tocopherol) loss reached up to $79 \%$ in four months, whereas $<45 \%$ of the phenols were lost under diffused light during storage (Okogeri and Tasioula-Margari, 2002). A positive correlation was found between the age of the oils and the tyrosol to total phenols ratio (Cinquanta et al., 1997). EVOO with high antioxidant contents was still "excellent" after 240 days of storage at $40{ }^{\circ} \mathrm{C}$ (Lavelli et al., 2006). Although an important loss of total phenol content was seen in commercial Arbequina virgin olive oil after 12 months of storage, no changes in some phenolics (tyrosol and hydroxytyrosol) and aromatic hydrocarbon contents of freezed samples were reported up to 12 months (Mulinacci et al., 2013). Psomiadou et al. (2000) suggested a good handling is quite important to keep high $\alpha$-tocopherol levels of Greek VOO under domestic conditions for two years.

Since Turkey is the motherland of olive trees, there are many minor olive varieties, produced and consumed in the local market. When the growers of these minor varieties have problems in processing or trading, they can leave these olive groves for something else. We wondered for these olive germplasms because they could be disappeared. Most of the minor olive varieties, like Tavşan Yüreği, have been processed for olive oil (and/or table olive) for centuries in their locations, but never in high-quality EVOO. So nobody has been known the real taste and the amount of minor compounds like polyphenol, contents of these olive oils. For that reason, we had prepared a project for design a mobile olive oil extraction unit in order to produce high quality olive oil from Tavşan Yüreği and other, not-well-known, minor varieties, in its origin. Tavşan Yüreği olive is originated and located mainly
Döşemealtı and Kepez villages of Antalya province, located in Western Mediterranean Region. The number of olive trees of Tavşan Yüreği cv. is about 250000 . Most of the trees are older than 90 years. Total yield is about 10000 tons per year. It is used mainly for green table olive and the rest processed for olive oil but for local consumption. While early harvesting fruit has $10 \%$ olive oil, at the end of ripening it increased up to $20 \%$ level. In this study, we aimed to perform the best processing method for olive oil production from Tavşan Yüreği olive cultivar grown locally in Antalya. For this purpose, a mobile olive oil processing unit was designed and used for cold press olive oil production. Chemical composition and sensory evaluation were monitored during 12 months' storage. The quality of Tavşan Yüreği oil was approved by the quality prize "Gold Award 2015" in Monocultivar Olive Oil Expo2015 in Milan and The New York International Olive Oil Competition.

\section{Materials and methods}

\subsection{Production of extra virgin olive oil (EVOO)}

Mobile Olive Oil Processing Unit (MOOPU) with stateof-the-art Oliomio equipment was designed in order to produce high-quality EVOO (Fig. 1). A special container was constructed and equipped with a knife crusher and a twophase horizontal decanter (Oliomio D500, Italy). The MOOPU is a unique olive extraction unit (with $600 \mathrm{~kg} / \mathrm{h}$ capacity industrial scale but laboratory conditions in terms of hygiene and quality) which was used for oil extraction. It is extremely important because there is no olive oil factory where the olives were processed at optimum conditions in the origin provinces of the local varieties. The mobile unit is an articulated lorry with a special semi-trailer measuring $2438 \times 12192 \times 2896 \mathrm{~mm}$ which is divided into three separate sections. The first section is the olive accepting unit including; bunker, leaf removers, washer and crusher units of the system. The second section is a processing unit including malaxer, decanter, filter, and bag-inbox filling machine. The third section is support unit placed a power plant and a water supply tank. Processing unit was equipped with an air conditioner, isolation and filter ventilation systems and protected for temperature changes, dust and odor. MOOPU carried by a trailer truck to orchards in the 2015-2016 season. Olive fruits (about one metric ton) were harvested by hand picking in the early harvest period and processed to "cold press" VOO in the MOOPU in one batch. The process was completed in a couple of hours. The olive paste was prepared after crushing by a hammer mill and the paste was mixed in the malaxer at $27^{\circ} \mathrm{C}$ for $15 \mathrm{~min}$ (Cold press). After decantation EVOO (about 100 liters) was filtered and filled in $250 \mathrm{ml}$ amber glass bottles (headspace: $4 \mathrm{~cm}$ ) by nitrogen gas. The bottles ( 24 bottles, 12 of them for chemical and 12 of them for sensorial analysis) were stored at room temperature $\left(18-24^{\circ} \mathrm{C}\right)$ up to 12 months.

\subsection{Chemical analysis}

Free fatty acid content and peroxide value were performed according to the EC 2598/91 (European Commission Regulation, 2013) and AOCS Cd 8-53 methods (2003), 

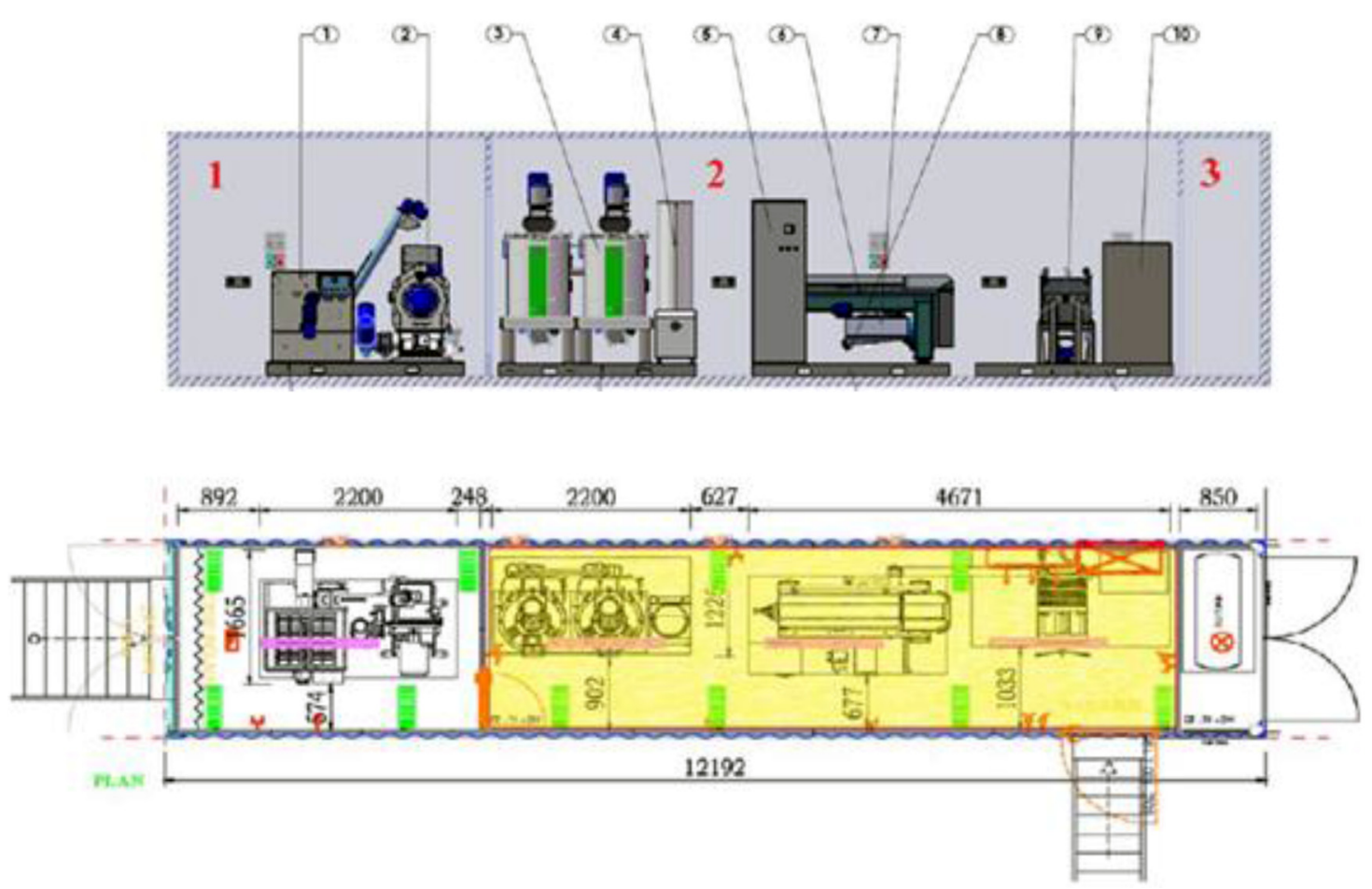

Fig. 1. Mobile Olive Mill (MOM) design. Section 1: olive accepting unit including; bunker, leaf removers, washer (1) and crusher (2); section 2: processing unit including malaxer (3), decanter (6), filter (9) and filling machine (10); section 3: support unit placed a power plant and a water supply tank.

respectively. Analytical grade chemical materials were used for free fatty acid content and peroxide value assays (ethanol, diethyl ether, acetic acid, chloroform). Color values ( $L, a, b$ values) were determined by spectrophotometry (Minolta, CM3600d, Japan). UV absorbance was performed according to the IOC method COI/T.20/Doc. No. 19/Rev. 3. The UV values were measured at 232, 266, 270 and $274 \mathrm{~nm}$ by using UV Spectrophotometer (Agilent 8453, USA). For this propose, $0.25 \mathrm{~g}$ olive sample was weighed in to $50 \mathrm{ml}$ falcon tube and $25 \mathrm{ml}$ cyclohexane was added on it. Falcon tube was shaken for $1 \mathrm{~min}$ and $1 \mathrm{ml}$ of this solution was filled in a quartz cuvette. $\Delta \mathrm{K}$ values were calculated with the following formula:

$\Delta \mathrm{K}=\mathrm{K}_{270}-\left[\left(\mathrm{K}_{266}+\mathrm{K}_{274}\right) / 2\right]$.

In the present study, chemical and sensory assays were performed monthly, but chromatographic analysis including total phenolic content, phenolic composition and tocopherol content were measured quarterly or every six months due to the slight changes on the minor compounds and limited project budget.

\subsection{Total phenolic content}

Polar fraction was extracted and used for total phenolic and phenolic composition analysis. Polar fraction was obtained according to the methods of Romani et al. (2007) and InarejosGarcía et al. (2009). $2.5 \mathrm{~g}$ of EVOO sample was weighed into a falcon tube. Hexane $(6 \mathrm{ml})$ was added and shaken for $1 \mathrm{~min}$. This solution was passed through solid phase extraction (SPE) cartridge (Superclean LC-Diol, USA) and collected in a glass tube. Then hexane $(6 \mathrm{ml})$ and $4 \mathrm{ml}$ hexane: ethyl acetate $(85: 15$, $\mathrm{v} / \mathrm{v})$ were passed through the SPE cartridge, respectively. The cartridge was washed with methanol: deionized water solution
$(1: 1, \mathrm{v} / \mathrm{v})$ and phenolic extract was evaporated (UniEquip Univapo $100 \mathrm{ECH}$, Canada). After addition of $2 \mathrm{ml}$ methanol: deionized water solution $(1: 1, \mathrm{v} / \mathrm{v})$ the tubes vortexed for $30 \mathrm{~s}$. For determination of total phenols, Folin \& Ciocalteu method was used and the results were expressed in terms of gallic acid equivalent (mg gallic acid/kg oil) (Romani et al., 2007; Inarejos-García et al., 2009). Ultra high-performance liquid chromatography (UHPLC, Thermo Scientific Dionex Ultimate 3000 , USA) and C18 column (4.6 mm inner diameter $\times 250$ $\mathrm{mm}$ length and $5 \mathrm{~mm}$ particle diameter; Thermo scientific acclaim 120) was used for determination of phenolic profile. Prepared phenolic extract $(1 \mathrm{ml})$ was filtered through $0.45 \mu \mathrm{m}$. Syringe filter (Merck, PVDF, Millipore Millex-HV, Germany) and poured into an amber vial. Column temperature was fixed at $30^{\circ} \mathrm{C}$ and acetic acid: deionized water (1:1, v/v) (A), methanol (B), acetonitrile (C) were used in a gradient flow program as the mobile phase. In the gradient program eluents were $2.5 \% \mathrm{~B}, 2.5 \% \mathrm{C}$, and $95 \% \mathrm{~A}$ solution up to $60 \mathrm{~min}$. The flow rate was $1 \mathrm{ml} / \mathrm{min}$ and diode array detector (DAD) detector was set in 280, 320 and $335 \mathrm{~nm}$. HPLC grade hexane, methanol, acetonitrile and ethyl acetate were used in total phenolic content and phenolic compounds assays. Apigenin, cafeic acid, gallic acid, luteolin, $m$-coumaric acid, $p$-coumaric acid, oleuropein, syringic acid, trans-ferulic acid, vanilic acid, vanillin, tyrosol, 3-hydroxy tyrosol, 3,4-dihydroxy benzoic acid, 4-hydroxy benzoic acid, 4-hydroxy phenyl acetic acid were used as standards.

For tocopherol composition, EVOO sample (2 g) was weighed into a $25 \mathrm{ml}$ volumetric flask (AOCS Official Method Ce 8-89, 1997). A quantity of hexane (HPLC grade) was added and shaked to dissolve the sample. Flask was made up to 
E. Ghanbari Shendi et al:: OCL 2020, 27, 6

Table 1. Oxidative stability parameters and color values of Tavşan Yüreği (Antalya) olive oils during 12 months of storage.

\begin{tabular}{|c|c|c|c|c|c|c|c|}
\hline $\begin{array}{l}\text { Storage } \\
\text { period (Month) }\end{array}$ & $\begin{array}{l}\text { Free fatty acid } \\
\text { content }(\%)\end{array}$ & $\begin{array}{l}\text { Peroxide value } \\
\left(\mathrm{meqO}_{2} / \mathrm{kg} \text { yağ }\right)\end{array}$ & $\mathrm{K}_{232}$ & $\mathrm{~K}_{270}$ & $L$ value & $a$ value & $b$ value \\
\hline 0 & $0.1 \pm 0.00^{\mathrm{c}}$ & $14.76 \pm 0.02^{\mathrm{i}}$ & $1.9 \pm 0.00^{\mathrm{f}}$ & $0.11 \pm 0.00^{\mathrm{i}}$ & $32.82 \pm 0.01^{\mathrm{a}}$ & $0.69 \pm 0.01^{\mathrm{f}}$ & $8.17 \pm 0.06^{\mathrm{d}}$ \\
\hline 2 & $0.2 \pm 0.00^{\mathrm{b}}$ & $16.23 \pm 0.06^{\mathrm{h}}$ & $0.3 \pm 0.00^{\mathrm{j}}$ & $0.67 \pm 0.00^{\mathrm{b}}$ & $33.24 \pm 0.04^{\mathrm{a}}$ & $0.94 \pm 0.01^{\mathrm{ef}}$ & $8.92 \pm 0.02^{\mathrm{cd}}$ \\
\hline 3 & $0.3 \pm 0.00^{\mathrm{a}}$ & $17.59 \pm 0.02^{\mathrm{g}}$ & $0.4 \pm 0.00^{\mathrm{i}}$ & $0.32 \pm 0.00^{\mathrm{d}}$ & $33.27 \pm 0.06^{\mathrm{a}}$ & $1.11 \pm 0.02^{\mathrm{def}}$ & $8.75 \pm 0.23^{\mathrm{cd}}$ \\
\hline 6 & $0.3 \pm 0.00^{\mathrm{a}}$ & $17.98 \pm 0.01^{\mathrm{f}}$ & $2.4 \pm 0.00^{\mathrm{c}}$ & $0.20 \pm 0.00^{\mathrm{f}}$ & $34.32 \pm 0.12^{\mathrm{a}}$ & $2.07 \pm 0.01^{\mathrm{abc}}$ & $11.03 \pm 0.08^{\mathrm{a}}$ \\
\hline 7 & $0.3 \pm 0.00^{\mathrm{a}}$ & $19.45 \pm 0.06^{\mathrm{e}}$ & $3.2 \pm 0.00^{\mathrm{a}}$ & $0.62 \pm 0.00^{\mathrm{c}}$ & $33.27 \pm 0.90^{\mathrm{a}}$ & $2.07 \pm 0.14^{\mathrm{abc}}$ & $9.85 \pm 1.08^{b c}$ \\
\hline 8 & $0.3 \pm 0.00^{\mathrm{a}}$ & $19.76 \pm 0.02^{\mathrm{d}}$ & $2.4 \pm 0.00^{\mathrm{c}}$ & $0.30 \pm 0.00^{\mathrm{e}}$ & $27.25 \pm 2.93^{c}$ & $1.06 \pm 0.09^{\mathrm{def}}$ & $3.16 \pm 0.69^{\mathrm{e}}$ \\
\hline 9 & $0.3 \pm 0.00^{\mathrm{a}}$ & $19.85 \pm 0.04^{\mathrm{d}}$ & $2.1 \pm 0.00^{\mathrm{e}}$ & $0.14 \pm 0.00^{\mathrm{j}}$ & $34.15 \pm 0.23^{\mathrm{a}}$ & $2.31 \pm 0.03^{\mathrm{a}}$ & $10.84 \pm 0.44^{\mathrm{a}}$ \\
\hline 10 & $0.3 \pm 0.00^{\mathrm{a}}$ & $20.64 \pm 0.00^{\mathrm{c}}$ & $2.5 \pm 0.00^{\mathrm{b}}$ & $0.17 \pm 0.00^{\mathrm{h}}$ & $29.75 \pm 0.81^{b}$ & $1.66 \pm 0.45^{\mathrm{bcd}}$ & $11.12 \pm 0.06^{\mathrm{a}}$ \\
\hline
\end{tabular}

${ }^{*}$ Different superscript letters $(\mathrm{a}-\mathrm{i})$ in the same column indicate significant differences between mean values $(P<0.01)$.

$\mathrm{N}=26$.

volume with the same solvent. The solution was passed from syringe filter $(0.45 \mu \mathrm{m})$ (PVDF, Millipore Millex-HV) in to the HPLC vial. The samples $(20 \mu l)$ were injected into an HPLC (UHPLC: Ultra-High Performance Liquid Chromatography (Dionex Ultimate 3000) equipped with. LiChrosorb SI 60-5 column $(4.6 \mathrm{~mm}$ I.D $\times 250 \mathrm{~mm}$ length and $5 \mu \mathrm{m}$ particle size $)$. Column temperature was fixed at $30^{\circ} \mathrm{C}$ during the process. Flow rate of analysis was $1 \mathrm{ml} / \mathrm{min}$. For mobile phase, isopropanol: hexane $(0.5: 99.5, \mathrm{v} / \mathrm{v})$ isocratic mix was used and chromatograms were collected at $292 \mathrm{~nm}$ wavelength. Analysis time was $30 \mathrm{~min}$ and the injection volume was $100 \mu$ l. Amounts of $\alpha, \beta, \gamma$ and $\Delta$ tocopherols were determined by using tocopherol standards.

\subsection{Sensory analysis}

Every month EVOO samples were evaluated by the Ayvalık Olive Oil Tasting Laboratory accredited by International Olive Council (IOC Regulation, 2015) and TURKAK (Turkish Accreditation Agency) according to the method for the organoleptic assessment of virgin olive oil (COI/T.20/Doc. No. 15/Rev. 8, November 2015). Eight trained tasting panels were able to assess the oils to determine the levels of positive attributes, such as fruitiness, bitterness and pungency. Negative attributes arising due to poor quality fruit, incorrect processing or storing, such as rancidity, musty and fusty, were determined by sensory panel. Descriptors were evaluated on a $0-10$ intensity scale (a number between 0 and 10 ).

\subsection{Statistical analysis}

Statistical analysis was performed by SPSS 17 (SPSS Inc. Chicago, IL) statistical software and using One-way ANOVA method. All analysis was performed at least duplicate for each month EVOO samples and differences among all groups were determined by Duncan test. The confidence level for statistical analysis was $99 \%$.

\section{Results}

\subsection{Chemical analysis}

Free fatty acidity, peroxide value and UV absorbance values of the olive oils extracted by Mobile Olive Oil Processing Unit (MOOPU) were shown in Table 1. Although a slight increase was observed during storage all samples could be classified as extra virgin olive oils according to the International Olive Oil Council (IOC) standards (Tab. 1). Free fatty acidy which is an important criterion for the classification of olive oils increased slightly in the third month and no change was observed until the end of storage time. It is well known that free acidity increased with storage depending on the packaging material, storage conditions and time (Lavelli et al., 2006; Clodoveo et al., 2007; Méndez and Falqué, 2007; Abdalla et al., 2014; Baiano et al., 2014).

Peroxide value (PV), which is the primary oxidation indicator, showed an increasing trend up to the end of the storage period (Tab. 1). The minimum level of PV was observed at the beginning of the storage. Significant increases were reported on the PV of olive oil samples from different cultivars during short-term ( 30 days) and long-term (6 years) storage in different packaging materials at different conditions (Okogeri and Tasioula-Margari, 2002; Lavelli et al., 2006; Clodoveo et al., 2007; Abdalla et al., 2014).

Absorption values $\left(\mathrm{K}_{232}\right.$ and $\left.\mathrm{K}_{270}\right)$ are one of the quality parameters and helps to differentiate between extra virgin, virgin and regular olive oil as defined by the International Olive Council (IOC). UV absorbance values $\left(\mathrm{K}_{232}\right.$ and $\left.\mathrm{K}_{270}\right)$ which are indicator of oxidation changed during storage significantly. A low absorption value is a sign of a high-quality extra virgin olive oil, whereas low-quality oil shows a greater level of absorptions in the UV region. UV absorbance values $\left(\mathrm{K}_{232}\right.$ and $\left.\mathrm{K}_{270}\right)$ which are advanced oxidation products changed during storage significantly $(P<0.01) . \mathrm{K}_{232}$ values decreased up to the third month. The sharp increase was 
Table 2. Tocopherol Content of Tavşan Yüreği (Antalya) olive oil monocultivar during 12 months' storage (ppm).

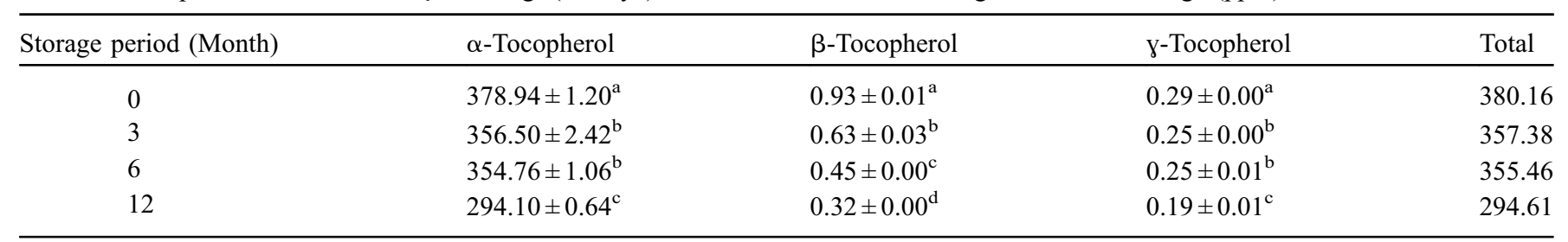

*Different superscript letters in the same column indicate significant difference between mean values $(P<0.01)$.

observed in the fourth, sixth and seventh month and it was stable near the end of storage time. The highest and the lowest $\mathrm{K}_{270}$ values were in the fifth and first months, respectively (Tab. 1). Except for second, third, fifth and seventh months of storage period, $\mathrm{K}_{270}$ values were under IOC (International Olive Council standards) limitations. $\Delta \mathrm{K}$ values were zero or below zero (results are not shown). These results are in agreement with the related literature (Okogeri and TasioulaMargari, 2002; Caponio et al., 2005; Del Caro et al., 2006; Lavelli et al., 2006; Gómez-Alonso et al., 2007; Méndez and Falqué, 2007; Baiano et al., 2014). Baiano et al. (2014) reported that $\mathrm{K}_{232}$ value of Coratina olive oil increased up to the sixth year, then it decreased and the end of storage an increase was observed. Gutiérrez and Fernández (2002) showed that $\mathrm{K}_{270}$ and sensory evaluation indices of Picual and Hojiblanca olive oils decreased during storage at $2{ }^{\circ} \mathrm{C}$ in darkness and $30^{\circ} \mathrm{C}$ in illumination.

\subsection{Color analysis}

Although the color is not regarded as an important quality feature for olive oil, it has a great influence on consumer acceptance. The color of virgin olive oils is depended on olive maturity and process conditions. Color values ( $L, a$ and $b$ values) were measured during storage. The maximum for $L$ is 100 , which would be a perfect reflecting diffuser. The minimum measuring for $L$ would be zero, which would be black. The $a$ and $b$ have no specific numerical limits. Positive $a$ is red and negative $a$ is green. Positive $b$ is yellow and negative $b$ is blue. Analysis of color ( $L, a$ and $b$ values) showed that the color of olive oil samples changed significantly during storage (Tab. 1). It has been attributed to decomposition of color pigments such as chlorophylls, pheophytins, xanthophylls and carotenes (Boskou, 2006). The lowest $L$ value (lightness) was seen in the eighth month. The $L$ values was increased to 34.15 after 9 months and then decreased lightly. Fluctuations were observed in $a$ (redness) and $b$ (yellowness) values during storage. The highest $b$ value was obtained for the tenth month. After this month there was a decreasing trend in $b$ value. The highest $a$ value also observed in ninth and twelfth months.

\subsection{Tocopherol profile}

There are four natural tocopherols $\alpha, \beta, \gamma, \delta$-forms are available in olive oil. The $\alpha$-tocopherol (vitamin E) is the major antioxidant (150 and $300 \mathrm{ppm}$ ) present in olive oil and it displays antioxidant properties and important role in the olive oil stability (Cert et al., 2000). Tocopherol $(\alpha, \beta, \gamma)$ profiles of the EVOO samples were determined every three months
Table 3. Changes in Total phenols of Tavşan Yüreği (Antalya) EVOOs during 12 months of storage (ppm).

\begin{tabular}{cl}
\hline Storage period (Month) & $\begin{array}{l}\text { Tavşan Yüreği EVOO } \\
\text { total phenols content }\end{array}$ \\
\hline 0 & $385.27 \pm 0.91^{\mathrm{a}}$ \\
3 & $365.35 \pm 1.02^{\mathrm{b}}$ \\
6 & $343.88 \pm 1.11^{\mathrm{c}}$ \\
9 & $335.26 \pm 0.46^{\mathrm{d}}$ \\
12 & $327.58 \pm 0.21^{\mathrm{e}}$
\end{tabular}

*Different superscript letters (a-e) in the same column indicate significant difference between mean values $(P<0.01)$.

during storage (Tab. 2). The results showed that total tocopherol content decreased from 380.16 to $294.61 \mathrm{ppm}$ with increasing storage time. The lowest tocopherols content was obtained at the end of storage. It means that $22.38 \%$ of $\alpha$-tocopherol, $65.59 \%$ of $\beta$-tocopherol and $34.48 \%$ of $\gamma$-tocopherol contents were decomposed during storage. Decreasing in $\alpha$-tocopherol was lower than other tocopherol isomers. Although a rise of $\alpha$-tocopherol content was observed for the Arbequina oils, decreases in this content between $47 \%$ and $70 \%$ for Picual and Hojiblanca oils were reported respectively, at $60^{\circ} \mathrm{C}$. (Escudero et al., 2016).

\subsection{Total polyphenolic compounds}

Phenolics are important minor components in olive oil which, the powerful antioxidant effect, contribute to shelf life stability and sensory properties of olive oil. Total polyphenol contents of the samples were presented in Table 3. The highest total polyphenol values were determined at fresh oil which decreased with time. But the decreases were not dramatic as well as tocopherols, after one year $15 \%$ of total polyphenols were decomposed in EVOO samples. Detrimental effects of factors such as oxygen, light, heat and time on phenol compounds of olive oil have been reported in a number of studies. After a short term or long term storage, significant decreases in total polyphenols were reported for monocultivar and commercial olive oils (Morelló et al., 2004; Clodoveo et al., 2007; Baiano et al., 2009; Abdalla et al., 2014, Baiano et al., 2014). The loss of phenolics among the varieties varied and this differences have been attributed to a result of initial differences in oil acidity (Brenes et al., 2001). In Turkey, phenolic contents of local monocultivar (Halhali, Egriburun, Hasebi, Karamani and Saurani) olive oils and commercial monocultivar (Gemlik, Memecik, Ayvalık, Uslu and Domat cv.) olive oils ranged 64-321 mg caffeic acid $/ \mathrm{kg}$ and 23.69-153.64 caffeic acid/kg respectively (Kara et al., 2018). 
Table 4. Changes in phenolic compounds of Tavşan Yüreği (Antalya) olive oils during 12 months of storage (ppm).

\begin{tabular}{|c|c|c|c|}
\hline & & Month & \\
\hline 3,4-dihydroxy benzoic acid & $3.88 \pm 0.01^{\mathrm{a}}$ & $3.82 \pm 0.01^{\mathrm{a}}$ & $3.75 \pm 0.01^{\mathrm{b}}$ \\
\hline 4-hydroxy benzoic acid & $8.45 \pm 0.05^{\mathrm{a}}$ & $7.40 \pm 0.33^{b}$ & $4.62 \pm 0.04^{\mathrm{c}}$ \\
\hline Syringic acid & $0.96 \pm 0.06^{\mathrm{a}}$ & $0.92 \pm 0.01^{\mathrm{a}}$ & $0.64 \pm 0.01^{\mathrm{b}}$ \\
\hline Apigenin & $6.34 \pm 0.25^{\mathrm{a}}$ & $5.55 \pm 0.20^{\mathrm{b}}$ & $3.76 \pm 0.02^{\mathrm{c}}$ \\
\hline
\end{tabular}

*Different superscript letters $(\mathrm{a}-\mathrm{c})$ in the same raw indicate significant difference between mean values $(P<0.01)$. nd: not detect.

\subsection{Phenolic profiles}

Phenolic profiles of the samples were determined every six months (Tab. 4). 3,4-dihydroxy benzoic acid, tyrosol, 4hydroxy benzoic acid, syringic acid, m-coumaric acid, luteolin, and apigenin were identified and quantified in the polar fraction of olive oils. Luteolin was the most abundant phenolic that has been identified for all samples. Except tyrosol, other phenolic compounds content decreased with storage. These results confirmed that filtration caused significant change in the phenolic profile. The main reason of this effect could attributed to the filtration process. Filtration process can decrease water-soluble phenolic content and antioxidant in VOO (Ngai and Wang, 2015). Yorulmaz (2009) reported that luteolin was the most abundant phenolic compound following trans-cinnamic acid and luteolin-7glucoside. They also quantified tyrosol, syringic acid, $p-$ coumaric acid, luteolin-7-glucoside, trans-cinnamic acid, luteolin and apigenin in Turkish olive oils extracted from different olive varieties. Montedoro et al. (1992) reported that dialdehydic form of elenolic acid linked to 3,4-dihydroxyphenyl ethanol (3,4-DHPEA), $p$-hydroxyphenyl ethanol ( $p$ HPEA), vanilic acid, cafeic acid, 3,4-DHPEA-EDA, 3,4DHPEA-EA had been identified in olive oils. Morelló et al. (2004) suggested that although storage did not appear to have any effect on vanilic acid or vanillin, which were present at low concentration there was a significant decrease in the concentration of the rest of the quantified phenolic compounds. That reduction was more marked in the secoiridoid derivatives such as dialdehydic form of elenolic acid linked to hydroxytyrosol (3,4-DHPEA-EDA), $p$-HPEA-EDA (dialdehydic form of elenolic acid linked to tyrosol) and 3,4-DHPEAEA (oleuropein

Aglycon) indicating a more active participation in the oxidative processes as they were more easily oxidized. Among the most representative phenolic compounds in olive oil, lignans seem to be the most stable during oil storage. García et al. (2003), Gómez-Alonso et al. (2007) and Mulinacci et al. (2013) showed an increase tyrosol and hydroxytyrosol contents over time due to hydrolytic processes of the secoiridoidic derivatives. Gómez-Alonso et al. (2007) stated that the main phenols were oleuropein aglycon, dialdehydic form of elenolic acid linked to tyrosol ( $p$-HPEA-EDA) and hydroxytyrosol (3,4-DHPEA-EDA). Baiano et al. (2014)

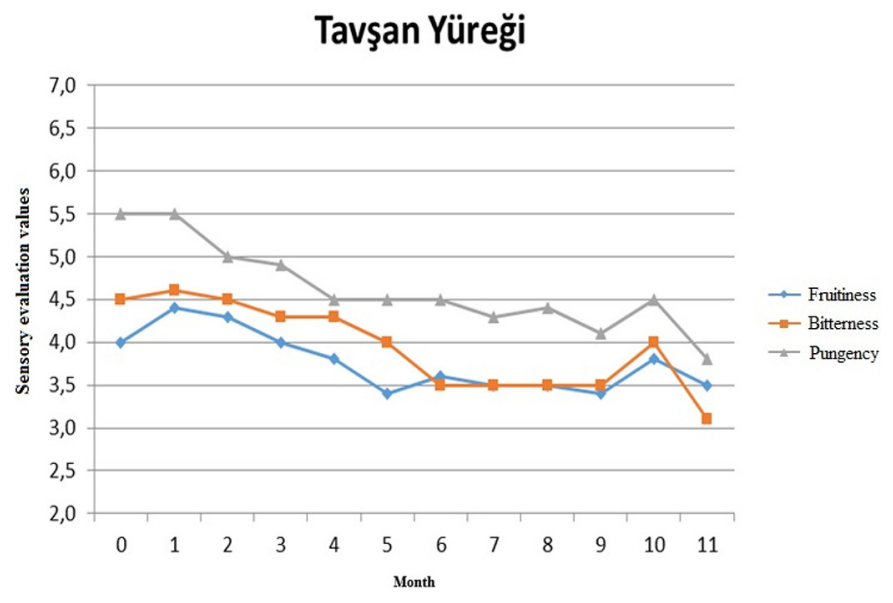

Fig. 2. Sensory values of Tavşan Yüreği (Antalya) olive oils during 12 months of storage.

reported that there were increasing and decreasing trends in phenolic compounds (3,4-DHPEA, $p$-HPEA, vanillin, $p$ coumaric acid, 4-(acetoxyethyl)-1,2-dihydrobenzene (3,4DHPEA-AC), 3,4-DHPEA-EDA, $p$-HPEA-AC, $p$-HPEAEDA, 1-acetoxipinoresinol + trans-cinnamic acid, $p$-HPEAEA) content.

\subsection{Sensory analysis}

Tavşan Yüreği extra virgin olive oil had a green fruity aroma characterized by caramel, honey, blossom, green apple, grass, freshly cut grass, almond and spring notes. It had nodefect and fruitness is higher than bitterness even pungency (Fig. 2). Fruitness decreased during a year storage time. It was received from 4 to 3.5 at the end of the year. So it has medium fruitiness according to IOC Regulation $(3.0<\mathrm{Me} \leq 6.0)$. During storage of samples, bitterness has been reduced from 4.5 to 3.1. The bitterness of EVOO samples changed in medium level $(3.0<\mathrm{Me} \leq 6.0)$. However, pungency was 4 out of 10 in the beginning and reduced from 5.5 to 3.5 in EVOO samples. Pungency also altered in the medium range $(3.0<$ $\mathrm{Me} \leq 6.0)$. Tasting panel did not detect any defects in the samples during whole a year storage time in room temperature. This can be attributed to the high amount of polyphenols. 
There are some compounds reported by different researchers to be the major components responsible for sensorial perceptions such as bitterness and pungency. Phenolic compounds, particularly secoiridoids generally decrease during EVOO storage. Because of the hydrolysis of secoiridoid derivatives in the hydroxytyrosol, tyrosol and elenolic acid and formation of oxidized phenols. By these reactions, bitterness and pungency which are positive attributes that are characteristic of a fresh EVOO, are decreasing (Bendini et al., 2009).

\section{Conclusion}

Tavşan Yüreği olive is harvested in small quantities from old trees in southwestern Anatolia especially Muğla and Antalya regions. Most of the minor olive varieties, like Tavşan Yüreği, have been processed for olive oil for centuries in their territories and these oils are not prominent due to their little recognition. Because generally small and/or damaged fruits that are not suitable for table olive production are used for olive oil production. To the best of our knowledge, this is the first work addressing EVOO extracted from Tavşan Yüreği cultivar in a pilot scale in terms of chemical and sensory properties.

The results obtained in this study showed that Tavşan Yüreği olive oils processed at optimum conditions have a unique sensory and chemical composition with a good oxidative stability due to high tocopherols and phenolics contents that are uncommon in most of the commercial olive oils in Turkey. Indeed, fresh EVOO had a sensory profile with the levels of intense fruitiness and medium bitterness and pungency with an equilibrated taste. Although fruitiness score decreased from intense to medium level other positive attributes (bitterness and pungency) were still medium level after one year. These results are of great importance to the olive oil industry for the production of high-quality monovarietal virgin olive oil from varieties with peculiar and differential characteristics and will provide some support to preserve Anatolia olive resources. According to the result of this study, mobile olive oil processing unit could be used for other local varieties in each origin province.

\section{Abbreviation}

$\begin{array}{ll}\text { EVOO } & \text { Extra virgin olive oil } \\ \text { VOO } & \text { Virgin olive oil } \\ \text { IOC } & \text { International Olive Council } \\ \text { MOOPU } & \text { Mobile Olive Oil Processing Unit }\end{array}$

Acknowledgment. This study was performed as a part of a project entitled "Improvement of Possibilities of Using Olive Genetic Resources in their Own Ecology by Conservation of Their Species Characteristics" The authors are grateful for the financial supports that were provided by the Republic of Turkey, Ministry of Science, Industry and Technology for financial supports (Project Number: SANTEZ-0560-STZ2013-2).

\section{References}

Abdalla IIH, Khaddor M, Boussab A, Garrouj DEl, Ayadi M. 2014. The effect of storage time on the quality of olive oil produced by cooperatives for olive growers in the North of Morocco. Asian J Agric Food Sci 02: 129-138.

American Oil Chemists' Society (AOCS). 1997. AOCS Official Method Ce 8-89. Determination of tocopherols and tocotrienols in vegetable oils and fats by HPLC.

American Oil Chemists' Society (AOCS). 2003. Cd 8-53. Official method for determining peroxide value acetic acid-chloroform.

Baiano A, Gambacorta G, Terracone C, Previtali MA, Lamacchia C, La Notte E. 2009. Changes in phenolic content and antioxidant activity of Italian extra-virgin olive oils during storage. J Food Sci 74(2): C177-83.

Baiano A, Terracone C, Viggiani I, Del Nobile MA. 2014. Changes produced in extra-virgin olive oils from cv. coratina during a prolonged storage treatment. Czech J Food Sci 32(1): 1-9.

Bendini A, Cerretani L, Salvador MDM, Fregapane G, Lercker G. 2009. Stability of the sensory quality of virgin olive oil during storage: An overview. Ital Food Beverage Technol 21: 389-406.

Brenes M, García A, García P, Garrido A. 2001. Acid hydrolysis of secoiridoid aglycons during storage of virgin olive oil. J Agric Food Chem 49(11): 5609-5614. https://doi.org/10.1021/ jf0107860.

Boskou D. 2006. Olive oil-Chemistry and technology. AOCS Press. https://doi.org/10.1159/000097916.

Caponio F, Bilancia MT, Pasqualone A, Sikorska E, Gomes T. 2005. Influence of the exposure to light on extra virgin olive oil quality during storage. Eur Food Res Technol 221: 92-98. https://doi.org/ 10.1007/s00217-004-1126-8.

Cert A, Moreda W, Perez-Camino MC. 2000. Chromatographic analysis of minor constituents in vegetable oils. J Chromatogr A 881: 131-148. https://doi.org/10.1016/s0021-9673(00)00389-7.

Cinquanta L, Esti M, La Notte E. 1997. Evolution of phenolic compounds in virgin olive oil during storage. $\mathrm{J} \mathrm{Am} \mathrm{Oil} \mathrm{Chem} \mathrm{Soc}$ 74: 1259-1264. https://doi.org/10.1007/s11746-997-0054-8.

Clodoveo ML, Delcuratolo D, Gomes T, Colelli G. 2007. Effect of different temperatures and storage atmospheres on Coratina olive oil quality. Food Chem 102: 571-576. https://doi.org/10.1016/j. foodchem.2006.05.035.

Del Caro A, Vacca V, Poiana M, Fenu P, Piga A. 2006. Influence of technology, storage and exposure on components of extra virgin olive oil (Bosana cv) from whole and de-stoned fruits. Food Chem 98: 311-316. https://doi.org/10.1016/j.foodchem.2005.05.075.

Escudero A, Ramos NM, La Rubia D, Pacheco R. 2016. Influence of extreme storage conditions on extra virgin olive oil parameters: Traceability study. J Anal Chem 2016: 1-10. http://dx.doi.org/ 10.1155/2016/7506807.

European Commission Regulation. 2013. Amending Regulation no. 2598/91, EU no. 1348/2013. Characteristics of olive oil and olive-residue oil and on the relevant methods of analysis. Off $J$ Eur Commun L338: 31-67.

García A, Brenes M, García P, Romero C, Garrido A. 2003. Phenolic content of commercial olive oils. Eur Food Res Technol 216: 520 525. https://doi.org/10.1007/s00217-003-0706-3.

Gómez-Alonso S, Mancebo-Campos V, Salvador MD, Fregapane G. 2007. Evolution of major and minor components and oxidation indices of virgin olive oil during 21 months storage at room temperature. Food Chem 100: 36-42. https://doi.org/10.1016/j. foodchem.2005.09.006.

Gutiérrez F, Fernández JL. 2002. Determinant parameters and components in the storage of virgin olive oil. Prediction of storage 
time beyond which the oil is no longer of "extra" quality. J Agric Food Chem 50: 571-577. https://doi.org/10.1021/jf0102158.

Inarejos-García AM, Androulaki A, Salvador MD, Fregapane G, Tsimidou MZ. 2009. Discussion on the objective evaluation of virgin olive oil bitterness. Food Res Int 42: 279-284. https://doi. org/10.1016/j.foodres.2008.11.009.

International Olive Council (IOC) Regulation. 2013. COI/T.15/NC No.3/Rev. 7. Trade standard applying to olive oils and olivepomace oils.

International Olive Council (IOC) Regulation. 2015. COI/T.20/Doc. No. 15/Rev. 8. Sensory analysis of olive oil, method for the organoleptic assessment of virgin olive oil.

International Olive Council (IOC) Regulation. 2015. COI/T.20/Doc. No. 19/Rev. 3. Spectrophotometric investigation in the ultraviolet.

Kara HH, Kıralan M, Çalışkan E, Bayrak A. 2018. Phenolic compounds of olive oils from Agean Region. Turk J Agric Food Sci Technol 6(1): 07-15.

Lavelli V, Fregapane G, Salvador MD. 2006. Effect of storage on secoiridoid and tocopherol contents and antioxidant activity of monovarietal extra virgin olive oils. J Agric Food Chem 54: 3002-3007.

Méndez AI, Falqué E. 2007. Effect of storage time and container type on the quality of extra-virgin olive oil. Food Control. https://doi. org/10.1016/j.foodcont.2005.12.012.

Montedoro G, Servili M, Baldioli M, Miniati E. 1992. Simple and hydrolyzable phenolic compounds in virgin olive oil. 1. Their extraction, separation, and quantitative and semiquantitative evaluation by HPLC. J Agric Food Chem 40: 1571-1576. https:// doi.org/10.1021/jf00021a019.

Morelló JR, Motilva MJ, Tovar MJ, Romero MP. 2004. Changes in commercial virgin olive oil (cv Arbequina) during storage, with special emphasis on the phenolic fraction. Food Chem 85: 357 364. https://doi.org/10.1016/j.foodchem.2003.07.012.

Mulinacci N, Ieri F, Ignesti G, et al. 2013. The freezing process helps to preserve the quality of extra virgin olive oil over time: A case study up to 18 months. Food Res Int 54: 2008-2015. https://doi. org/10.1016/j.foodres.2013.03.052.

Ngai C, Wang S. 2015. Filter or not? A review of the influence of filtration on extra virgin olive oil. Igarss: UC Davis Olive Center, pp. 1-14.

Okogeri O, Tasioula-Margari M. 2002. Changes occurring in phenolic compounds and alpha-tocopherol of virgin olive oil during storage. J Agric Food Chem 50: 1077-1080. https://doi.org/ 10.1021/jf010895e.

Psomiadou E, Tsimidou M, Boskou D. 2000. Alpha-tocopherol content of Greek virgin olive oils. J Agric Food Chem 48: 1770-1775.

Romani ANR, Apucci CHL, Antini CLC, Eri FRI, Ulinacci NAM, Isioli FRV. 2007. Evolution of minor polar compounds and antioxidant capacity during storage of bottled extra virgin olive oil. J Agric Food Chem 55: 1315-1320.

Yorulmaz A. 2009. Determination of phenolic compounds, sterol and triglycerides structures of Turkish olive oils. Doctorate Thesis, Institute of Science and Technology, Ankara University, Turkey.

Cite this article as: Ghanbari Shendi E, Sivri Ozay D, Ozkaya MT, Ustunel NF. 2020. Determination of chemical parameters and storage stability of extra virgin olive oil extracted by Mobile Olive Oil Processing Unit. OCL 27: 6. 